\title{
Effect of dietary prebiotic inulin and probiotic Bacillus subtilis and Lactobacillus sp., on the intestinal microbiota of white shrimp Litopenaeus vannamei
}

\author{
Efecto de la inclusión de inulina (prebiótico) y Bacillus subtilis y Lactobacillus sp. (probiótico) en el \\ alimento, sobre la microbiota intestinal del camarón blanco Litopenaeus vannamei
}

\author{
Cristina Escobedo-Fregoso', Eduardo Quiroz-Guzmán', Gabriela Mendoza-Carrion², Alberto Peña-Rodríguez* \\ CONACYT - CIBNOR, S.C., Instituto Politécnico Nacional 195, La Paz, B.C.S. 23096, Mexico. \\ 2 Centro de Investigaciones Biológicas del Noroeste, Col. Playa Palo de Santa Rita, La Paz, B.C.S., 23096, Mexico.
}

\section{ABSTRACT}

Juvenile Litopenaeus vannamei $(1.05 \pm 0.1 \mathrm{~g})$ were fed during a 4-week period with four experimental diets: control (Ctrl), inulin as prebiotic $\left(5 \mathrm{~g} \mathrm{~kg}^{-1}\right)$ (Pre), Bacillus subtilis and Lactobacillus sp. as probiotic $\left(1 \times 10^{5} \mathrm{CFU} \mathrm{g}^{-1}\right)$ (Pro), and a mix of inulin $+B$. subtilis and Lactobacillus sp. $\left(5 \mathrm{~g} \mathrm{~kg}^{-1}+1 \times 10^{5} \mathrm{CFU}\right.$ $\mathrm{g}^{-1}$ ) (Syn). Syn diet fed shrimps showed a significantly better utilization of feed and higher growth than those in control diet $(P<0.05)$. The probiotic employed induced higher intestinal bacterial richness, whereas inulin induced higher bacterial diversity in shrimp intestine. The most dominant bacterial phylum in the shrimp intestine among treatments was Proteobacteria with an abundance ranging between 80 and $84 \%$. Prebiotic diet (Pre) increased relative abundance of Firmicutes in shrimp intestine ( $2 \%$ ) compared to the rest of the treatments $(0.6 \%)$. When probiotics were included in the feed (Pro and Syn), a reduction between 3 and $13 \%$ in the relative abundance of Vibrio sp. in shrimp intestine was observed with respect to the control treatment, which represent an advantage to control potential pathogens of this genus.

Keywords: Functional feed, Shrimp, Bacterial modulation.

\section{RESUMEN}

Juveniles de Litopenaeus vannamei $(1.05 \pm 0.1 \mathrm{~g})$ fueron alimentados durante cuatro semanas con cuatro dietas experimentales: control (Ctrl), inulina como prebiótico $(5 \mathrm{~g}$ $\mathrm{kg}^{-1}$ ) (Pre), Bacillus subtilis y Lactobacillus sp. como probiótico $\left(1 \times 10^{5}\right.$ UFC $\left.^{-1}\right)$ (Pro), y una mezcla de inulina $+B$. subtilis y Lactobacillus sp. (5 g kg-1 $+1 \times 10^{5}$ UFC g-1) (Syn). Los camarones con la dieta Syn resultaron en un crecimiento significativamente mayor y una mejor eficiencia de utilización del alimento que los camarones control $(P<0.05)$. El probiótico empleado indujo una mayor riqueza bacteriana intestinal, mientras que la inulina resultó en una mayor diversidad bacteriana en el intestino del camarón. A nivel de filo, Proteobacteria fue el más dominante en todos los tratamientos, entre 80 y el $84 \%$. La dieta Pre aumentó la abundancia relativa de Firmicutes en el camarón ( $2 \%$ ) en comparación con el resto de los tratamientos (0.6 \%). El uso del probiótico (Pro y Syn), resultó en una reducción de entre 3 y $13 \%$ en la abundancia relativa de Vibrio sp. en intestino de camarón respecto al tratamiento control, que representa una ventaja para el control de potenciales patógenos de este género.

Palabras clave: Alimentos funcionales, Camarón, Modulación bacteriana.

\section{INTRODUCTION}

The rapid worldwide expansion of farmed shrimp has faced different challenges in terms of pathogen outbreaks and demand for functional feeds that promote optimal growth and health. In the past decades, the control of shrimp diseases has been through chemicals and antibiotics; however, their indiscriminate use, as preventive strategy, resulted in the resistance by pathogens and environmental problems (Martinez, 2009). In different studies, the use of probiotics, natural prebiotics and synbiotics (combination of probiotics and prebiotics) added to the feed or in the culture water conferred health benefits to the host (Hai, 2015; Ringø et al., 2010; Olmos et al., 2020). Furthermore, this has been proposed to replace the use of chemicals and antibiotics to control and prevent shrimp diseases (Luna-González et al., 2012; Jamal et al., 2019; Partida-Arangure et al., 2013).

In the case of probiotics, some criteria to select beneficial microorganisms are the mode of action to enhance the immune response, production of inhibitory compounds to exclude pathogens, growth enhancement and improvement of water quality (Kesarcodi-Watson et al., 2008; Verschuere et al., 2000). Another determinant factor in the effectiveness of probiotics in aquaculture, is the origin of the microorganisms employed, where non-native bacteria from the marine environment may have poor success (Ninawe and Selvin, 2009) or represent a risk for the marine microbial ecology (VargasAlbores et al., 2017). It has also been suggested that multiple probiotic strains have better results than a single probiotic strain in relation to growth and health of shrimp (Wang et al., 2019). Two of the most studied bacterial genus employed as probiotics for farmed shrimp are Bacillus and Lactobacillus, which have been described to improve shrimp growth when supplemented in the feed (Kongnum and Hongpattarakere, 2012; Zheng et al., 2017; Wang et al., 2019). This is attributed in part to an increase in digestive enzymes activity (Liu et al., 2009; Zheng and Wang, 2017; Zhou et al., 2009). In addition, the administration of Bacillus sp. to water has been considered to improve survival rate and growth of shrimp larvae and water quality (Liu et al., 2010; Zhou et al., 2009). The use of

*Autor para correspondencia: Alberto Peña Rodríguez Correo electrónico: apena@cibnor.mx

Recibido: 17 de febrero 2021

Aceptado: 17 de mayo de 2021 
Lactobacillus sp. and Bacillus subtilis as probiotics, has also proved to protect against pathogenic bacteria in shrimp (Balcázar and Rojas-Luna, 2007) and brine shrimp culture (Quiroz-Guzmán et al., 2018).

On the other hand, prebiotics are non-digestible complex carbohydrates that promotes growth of beneficial bacteria in the intestinal tract of the host (Manning and Gibson, 2004). Among prebiotics used in shrimp diets, inulin may promote shrimp growth (Zhou et al., 2020) as well as the immune defense in infected shrimp (Luna-González et al., 2012; Partida-Arangure et al., 2013). The mix of different probiotics and prebiotics (synbiotics) included in shrimp feed has also shown improvement on growth, feed conversion ratio (FCR), and the immune response (Wongsasak et al., 2015; Zubaidah et al., 2015).

Microorganisms contribute to the biosecurity, nutrition, animal health, and other management aspects that are crucial in productivity of shrimp culture ponds (Kumar et al., 2015; Martínez-Córdova et al., 2015). Nevertheless, the lack of capacities for the culture of most bacteria species makes difficult the study of microbial communities and their interaction with the host (Rashid and Stingl, 2015). The knowledge of how prebiotics and probiotics, or a mix of them, influence bacterial communities in shrimp gut is scarce. However, the probiotics and prebiotics in shrimp culture promote differential gastrointestinal communities compared to basal diets ( $\mathrm{Li}$ et al., 2007; Vargas-Albores et al., 2017), increasing bacterial population and diversity, and, in some cases, promoting intestinal colonization of the probiotic employed (Wongsasak et al., 2015; Zubaidah et al., 2015). Different studies revealed that Vibrionaceae are ubiquitous in aquatic environments including culture ponds (Alagappan et al., 2010; Thompson et al., 2004), and considered causal agents of a major disease that causes high mortalities of farmed shrimps, including Litopenaeus vannamei (Novriadi, 2016; Zhou et al., 2012).

Using $16 \mathrm{~S}$ rRNA next-generation sequencing, this study aims to contribute to the understanding of the impact and importance of prebiotics, probiotics or synbiotics in feed on the intestinal bacterial communities of the white shrimp L. vannamei.

\section{MATERIAL AND METHODS}

\section{Bacterial strains and encapsulation}

The probiotic bacteria Bacillus subtilis (BSB) (Balcázar and Rojas-Luna, 2007) and Lactobacillus sp. (Cb-Lta) (García-Rodríguez 2003) were previously isolated from farmed $L$. vannamei. Both strains were grown on marine agar (MA) plates (seawater at $0.5 \%$ meat peptone, $0.1 \%$ yeast extract, and $1.7 \%$ agar), at $35{ }^{\circ} \mathrm{C}$ during $24 \mathrm{~h}$. The optical density of each bacteria was adjusted in a $2.5 \% \mathrm{NaCl}$ buffer to 1 at $600 \mathrm{~nm}\left(\mathrm{OD}_{600}=1\right)$ using a BioPhotometer (Eppendorf D30, NY, USA), to standardize the number of bacteria at $\sim 1 \mathrm{x}$

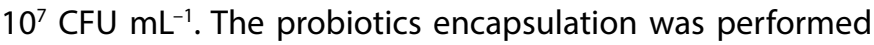
by mixing equal parts of both bacteria in a sterile solution of $2 \%$ low viscosity alginic sodium (Sigma Aldrich). The mixture was added dropwise using a syringe $(0.55-\mathrm{mm}$ diameter) into a $2 \% \mathrm{CaCl}_{2}$ solution while stirring magnetically. After filtered and washed with distilled water, capsules were stored at $4{ }^{\circ} \mathrm{C}$ in a sterile flask.

\section{Experimental diets}

Four balanced experimental diets were formulated for shrimp: a control diet (Ctrl), a prebiotic diet with inulin included at $0.5 \%$ (Pre), the third diet with the encapsulated probiotic at a final concentration of $1 \times 10^{5} \mathrm{CFU} \mathrm{g}^{-1}$ of each bacteria (Pro), and finally a synbiotic diet containing the same ratio of both prebiotic and probiotic (Syn) (Table 1). Manufactured diets were prepared as follows: all dry ingredients, including probiotic and prebiotic if applicable, were mixed (KitchenAid ${ }^{\oplus} 4.7 \mathrm{~L}$ mixer, Michigan, US) to obtain a homogeneous blend, followed by the incorporation of the oil-based ingredients and remixed. Then, distilled water was incorpo-

Table 1. Ingredients and proximate composition of experimental diets. Tabla 1. Ingredientes y composición proximal de los alimentos experimentales.

\begin{tabular}{|c|c|c|c|c|}
\hline \multirow[b]{2}{*}{ Ingredients ( $\mathrm{g} \mathrm{kg}^{-1}$ as is) } & \multicolumn{4}{|c|}{ Experimental feeds } \\
\hline & Ctrl & Pre & Pro & Syn \\
\hline Fish meal $^{a}$ & 220 & 220 & 220 & 220 \\
\hline Soybean meal ${ }^{\mathrm{b}}$ & 304 & 304 & 304 & 304 \\
\hline Wheat meal ${ }^{c}$ & 392.4 & 387.4 & 392 & 387 \\
\hline Fish oil a & 25 & 25 & 25 & 25 \\
\hline Soy lecithin ${ }^{d}$ & 35 & 35 & 35 & 35 \\
\hline Carboxymethyl cellulose ${ }^{\mathrm{e}}$ & 15 & 15 & 15 & 15 \\
\hline Vitamin-mineral premix ${ }^{f}$ & 5.3 & 5.3 & 5.3 & 5.3 \\
\hline Vitamin $C^{g}$ & 1 & 1 & 1 & 1 \\
\hline Choline Chloride $^{\mathrm{h}}$ & 1.5 & 1.5 & 1.5 & 1.5 \\
\hline $\begin{array}{l}\text { Sodium phosphate, } \\
\text { dibasic }^{\text {h }}\end{array}$ & 0.5 & 0.5 & 0.5 & 0.5 \\
\hline Antioxidant $\mathrm{BHT}^{\mathrm{h}}$ & 0.3 & 0.3 & 0.3 & 0.3 \\
\hline Inulin (prebiotic) ${ }^{\mathrm{i}}$ & 0 & 5 & 0 & 5 \\
\hline $\begin{array}{l}\text { Bacillus:Lactobacillus } \\
\text { (probiotic) }\end{array}$ & 0 & 0 & 0.4 & 0.4 \\
\hline \multicolumn{5}{|c|}{ Proximate composition (g $100 \mathrm{~g}^{-1}$ dry matter \pm SD) } \\
\hline Dry matter & $91.7 \pm 0.5$ & $91.5 \pm 0.4$ & $91.3 \pm 0.5$ & $91.8 \pm 0.3$ \\
\hline Protein & $38.1 \pm 0.2$ & $37.9 \pm 0.1$ & $37.8 \pm 0.2$ & $37.9 \pm 0.1$ \\
\hline Lipids & $7.9 \pm 0.1$ & $7.9 \pm 0.1$ & $8.0 \pm 0.1$ & $8.0 \pm 0.1$ \\
\hline Crude fiber & $1.2 \pm 0.04$ & $1.5 \pm 0.06$ & $1.2 \pm 0.03$ & $1.5 \pm 0.06$ \\
\hline Ash & $8.4 \pm 0.03$ & $8.4 \pm 0.03$ & $8.4 \pm 0.01$ & $8.4 \pm 0.03$ \\
\hline NFE $^{j}$ & 44.3 & 44.3 & 44.6 & 44.2 \\
\hline
\end{tabular}

a PMA S.A. de C.V., Jalisco, MX.

${ }^{b}$ PIASA S.A. de C.V., Baja California Sur, MX.

'Molino San Cristóbal, Sonora, MX.

d Suministros AZ, Baja California Sur, MX.

e IMSA SA de CV, Mexico City, MX.

fVitamin-mineral premix: detailed content in Elizondo-González et al. (2018)

${ }^{g}$ Rovimix Stay C 35\%, DSM, Heerlen, NL.

${ }^{\mathrm{h}}$ Sigma Aldrich, St. Louis, Missouri, US.

¿ Casa Alma de Provinciana, Jalisco, MX.

${ }^{J}$ Nitrogen-free extract

SD: standard deviation. 
rated and homogenized $\left(\sim 350 \mathrm{~mL} \mathrm{~kg}^{-1}\right)$, and finally passed through a 2-mm die (Torrey ${ }^{\circledR} \mathrm{M}-12-\mathrm{FS}$, Nuevo Leon, MX). The pelleted diets were dried in an oven at $35^{\circ} \mathrm{C}$ for $12 \mathrm{~h}(\sim 10 \%$ moisture) and kept in plastic bags at $4{ }^{\circ} \mathrm{C}$ until further use. Proximate composition analysis of shrimp diets was conducted as follows: dry matter was estimated by gravimetric analysis using a force-air oven at $100^{\circ} \mathrm{C}$ for $24 \mathrm{~h}$ (Method 930.15 ; AOAC, 2005). The crude protein content was estimated by the Dumas combustion method (Ebeling, 1968) with a LECO ${ }^{\circledR}$ FP-528 analyzer (LECO Inc., Michigan, US). The ether extract content was determined using a micro Foss Soxtec ${ }^{\circledR}$ Avanti 2050 (Foss, Hoganäs, SE) (Method 2003.05; AOAC, 2005). Ash content was analyzed gravimetrically at $550^{\circ} \mathrm{C}$ for $6 \mathrm{~h}$ with a furnace (Method 942.05; AOAC, 2005). Crude fiber (Method 978.10; AOAC, 2005) was determined using a Fibre $\mathrm{Tec}^{\circledast} \mathrm{M} 6$ System (Foss, Hoganäs, SE). Nitrogen-free extract (NFE) was estimated by difference ( $100 \%$ less the percentages of lipids, crude protein, ash and crude fiber). Gross energy was analyzed with an adiabatic calorimeter (Parr Instruments, model 1261, llinois, US). All experimental diets presented similar protein, lipid, and ash contents with a slight increase of crude fiber when inulin was included (Pre and Syn diets) (Table 1).

\section{Feeding trial}

Juvenile shrimp L. vannamei were kindly donated by Larvas Gran Mar, S.A. de C.V. (Baja California Sur, Mexico), acclimated to laboratory indoor conditions $\left(28 \pm 0.6{ }^{\circ} \mathrm{C},>4 \mathrm{mg}\right.$ $\mathrm{L}^{-1} \mathrm{DO}, 16: 8 \mathrm{~h}$ dark:light photoperiod and $37 \% 0$ salinity) for one week prior feeding trial. Experimental dietary treatments were evaluated by triplicate during 28 days; each replicate corresponded to a 50-L aerated fiberglass tank containing 10 shrimps (initial avg. wt. of $1.05 \pm 0.1 \mathrm{~g}$ ). Shrimps were fed to satiety for all treatments with two initial rations corresponding to $5 \%$ of shrimp biomass (09:00 and 15:00 h). Every day, the feed ration was adjusted according to consumption in each tank. Every day $50 \%$ water was exchanged, to keep water parameters of dissolved oxygen $\left(4 \pm 1.1 \mathrm{mg} \mathrm{L}^{-1}\right)$ and temperature $\left(28 \pm 0.5^{\circ} \mathrm{C}\right)$ which were measured daily with a multiparameter YSI model 85. Twice a week, $\mathrm{pH}(7.9 \pm 0.1)$ was analyzed using a Bluelab ${ }^{\oplus}$ pHmeter, and $\mathrm{NH}_{3}-\mathrm{N}(<0.25$ $\left.\mathrm{mg} \mathrm{L}^{-1}\right), \mathrm{NO}_{2}^{-}\left(<0.5 \mathrm{mg} \mathrm{L}^{-1}\right)$, and $\mathrm{NO}_{3}\left(<0.5 \mathrm{mg} \mathrm{L}^{-1}\right)$ were measured with an $\mathrm{API}^{\circledast}$ saltwater colorimetric kit. At the end of the feeding trial, shrimp performance was evaluated in terms of percentage of growth, specific growth rate (SGR), and percentage of survival; feed efficiency utilization was evaluated as feed conversion ratio (FCR) and protein efficiency ratio (PER).

The results of shrimp performance parameters were evaluated for normality (Shapiro-Wilk test) and homoscedasticity (Levene's test) using the software SPSS Statistics version 17.0. Data were subjected to one-way analysis of variance (ANOVA), followed by Tukey's multiple comparison tests if applicable ( $95 \%$ confidence).

\section{5 library preparation and sequencing}

After 28 days of the experimental feeding period, shrimp intestines carefully removed using sterile scissors and dissection forceps, were washed with sterile nuclease-free water. Each intestine was placed in absolute ethanol and stored at $-80^{\circ} \mathrm{C}$. The quality of DNA extracted from intestine tissue as described by Peña-Rodríguez et al. (2020), was determined by electrophoresis in $1.2 \%$ agarose gels, and quantified with a Qubit ${ }^{\circledR} 3.0$ fluorometer (Thermo Fisher Scientific). The PCR amplification was performed targeting the V3-V4 region of the bacterial 16S rRNA gene using primers V3 (5'-TCGTCGGCAGCGTCAGATGTGTATAAGAGACAGCCTACGGGNGGCWGCAG-3') and V4 (5'-GTCTCGTGGGCTCGGAGATGTGTATAAGAGACAGGACTACHVGGGTATCTAATCC-3') (Klindworth et al., 2013). PCR was carried out as follows: initial denaturation step at $95^{\circ} \mathrm{C}(5 \mathrm{~min})$, followed by 35 cycles of denaturation at $95^{\circ} \mathrm{C}(30 \mathrm{~s})$, annealing at $55^{\circ} \mathrm{C}(30 \mathrm{~s})$, and elongation at $72{ }^{\circ} \mathrm{C}(1 \mathrm{~min})$, followed by a final extension step at $72^{\circ} \mathrm{C}$ ( $5 \mathrm{~min}$ ). The amplicon size (550 bp) was verified by electrophoresis in $1 \%$ agarose gels, and purified using AMPure XP (A63881, Beckman Coulter, California, US). The second PCR reaction was performed using Nextera index kit V2 (FC-121-1011, Illumina). Amplification was performed as follows: initial denaturation step at $95^{\circ} \mathrm{C}(3 \mathrm{~min})$, eight cycles of denaturation at $95^{\circ} \mathrm{C}(30 \mathrm{~s})$, annealing at $55^{\circ} \mathrm{C}(30 \mathrm{~s})$, and elongation at $72{ }^{\circ} \mathrm{C}(30 \mathrm{~s})$, and a final extension at $72{ }^{\circ} \mathrm{C}(5$ min). The final PCR product was purified using AMPure XP. Library normalization of the 12 libraries (4 per treatment) was performed as described by Peña-Rodríguez et al. (2020). Libraries were sequenced on a MiSeq sequencing system (CIBNOR, La Paz, B.C.S., Mexico) using the Nano v2 flow cell of 300 cycles (MS-103-1001, Illumina).

\section{Bioinformatic analyses}

The raw reads were quality-trimmed using the Galaxy version 20.09 (The Institute for CyberScience at Penn State, and Johns Hopkins University) (http://usegalaxy.org) and aligned using the SILVA v138 database (Yilmaz et al. 2014). The sequences were randomly subsampled to normalize the number of sequences and assigned to operational taxonomic units (OTUs) based on $97 \%$ similarity. The structural diversity of the microbial communities was calculated with three indices, including Chao, Shannon, and Simpson, calculated by a binary matrix using PAST software (Hammer et al., 2001) (http://palaeo-electronica.org).

\section{RESULTS}

After 28 days of the feeding trial, all treatments resulted in at least $1.0 \mathrm{~g}$ weight gain per week, nevertheless shrimp fed Syn diet resulted in significantly higher growth rate, and SGR compared to shrimp under Ctrl and Pre feeding treatments $(P<0.05)$. The Syn diet showed a significant improvement in feed utilization in terms of FCR and PER compared to the Ctrl diet $(P<0.05)$, but it was not significantly different from Pre and Pro treatments. Survival of shrimp was $\geq 93 \%$ for all treatments $(P>0.05)$ (Table 2 ).

Each library had $36,278-59,857$ raw reads, and after quality control, 33,199-53,250 reads remained per library 
Table 2. Growth, feed efficiency and survival of Litopenaeus vannamei shrimps fed experimental diets after 4-weeks.

Tabla 2. Crecimiento, eficiencia de utilización de alimento y supervivencia de Litopenaeus vannamei después de 4 semanas de alimentación con las dietas experimentales.

\begin{tabular}{lcccc}
\hline & \multicolumn{4}{c}{ Diets } \\
\cline { 2 - 5 } & Ctrl & Pre & Pro & Syn \\
\hline Growth rate (\%) & $381 \pm 4^{\mathrm{a}}$ & $378 \pm 11^{\mathrm{a}}$ & $390 \pm 12^{\mathrm{ab}}$ & $403 \pm 3^{\mathrm{b}}$ \\
SGR (\% day $\left.{ }^{-1}\right)$ & $5.61 \pm 0.03^{\mathrm{a}}$ & $5.58 \pm 0.08^{\mathrm{a}}$ & $5.68 \pm 0.09^{\mathrm{ab}}$ & $5.77 \pm 0.02^{\mathrm{b}}$ \\
FCR & $1.56 \pm 0.03^{\mathrm{b}}$ & $1.50 \pm 0.05^{\mathrm{ab}}$ & $1.47 \pm 0.02^{\mathrm{ab}}$ & $1.45 \pm 0.03^{\mathrm{a}}$ \\
PER & $1.84 \pm 0.03^{\mathrm{a}}$ & $1.94 \pm .0 .07^{\mathrm{ab}}$ & $1.97 \pm 0.02^{\mathrm{ab}}$ & $2.01 \pm 0.04^{\mathrm{b}}$ \\
Survival (\%) & $97 \pm 6$ & $93 \pm 6$ & $93 \pm 6$ & $97 \pm 6$ \\
\hline
\end{tabular}

Values are given as mean \pm SD of triplicate determinations. Values in the same row with different superscripts are significantly different $(P<0.05)$. Growth rate $=($ final wt - initial wt $) \div$ initial wt $\times 100$.

SGR: Specific growth rate $=100$ (In avg final wt - In avg initial wt)/ d.

FCR: Feed conversion ratio $=$ dry weight of pelleted feed consumed $(g) \div$ wet wt gain $(\mathrm{g})$.

PER: Protein efficiency ratio = wt gain/feed protein intake.

Survival $=$ final number of shrimp/initial number shrimp $\times 100$.

with a total of 538,446 reads $(n=12)$. One library of the prebiotic treatment was identified as an outgroup replicate according to a principal component analysis, and was eliminated from subsequent analyses. The analyses clustered the sequences into 9,247 OTUs. At phylum level, shrimps fed with the four treatments (Figure 1) revealed that the most dominant bacterial phylum of the shrimp intestine was Proteobacteria with $80 \%$ in Ctrl diet, $82 \%$ in Pre and Pro diets, and the highest percentage was in Syn diet with $84 \%$. Within Proteobacteria phylum, control diet showed the highest relative proportion (42\%) in Gammaproteobacteria class compared to the rest of treatments, in which Pro diet presented a significant reduction of this bacteria group (23 $\%)$. In contrast, Alphaproteobacteria in control diet resulted in the lowest relative proportion (34\%) respect to the other diets (41-53\%). The second dominant bacterial phylum was Bacteroidetes, with the highest proportion in control diet (16 $\%)$, and the rest of the treatments resulted in the range of 11 to $13 \%$. The third dominant phylum was Actinobacteria with 2-3\% among treatments. Firmicutes phylum includes the probiotics used, where the highest proportion was present in the prebiotic-treatment group with $2 \%$, whereas the rest of treatments showed $0.6 \%$.

At Order taxa level (Figure 2), Rhodobacteriales was the most abundant bacteria in shrimp among treatments, and mostly represented by Rhodobacteraceae bacterial family (> $97 \%$ ). Shrimps fed with Pro diet probiotic showed the highest proportion of Rhodobacteraceae (53\%), followed by prebiotic and synbiotic treatments ( 41 and $40 \%$, respectively), and the lowest abundance was found in the control diet (34 \%). The most abundant genus present in Rhodobacteraceae among treatments was Octadecabacter with $11 \%$ of abundance for control, $12 \%$ for prebiotic, $14 \%$ for synbiotic, and $19 \%$ for probiotic treatment.

The second most abundant bacteria order among treatments was Vibrionales (Figure 2), manly from Vibriona-

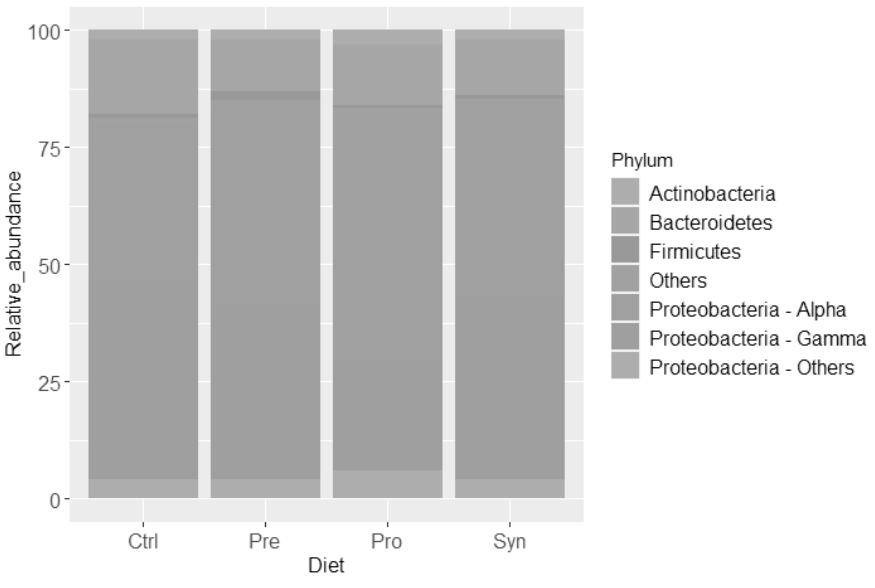

Figure 1. Relative abundance (\%) of bacterial, at phylum level (Proteobacteria divided at class taxa level), in shrimps fed during 4-weeks with the control (Ctrl), prebiotic (Pre), probiotic (Pro), and symbiotic (Syn) diets. Figura 1. Abundancia relativa (\%) de bacterias a nivel de filo (Proteobacteria dividido a nivel de clase) en camarones alimentados durante 4 semanas con las dietas control (Ctrl), prebiótica (Pre), probiótica (Pro) y simbiótica (Syn).

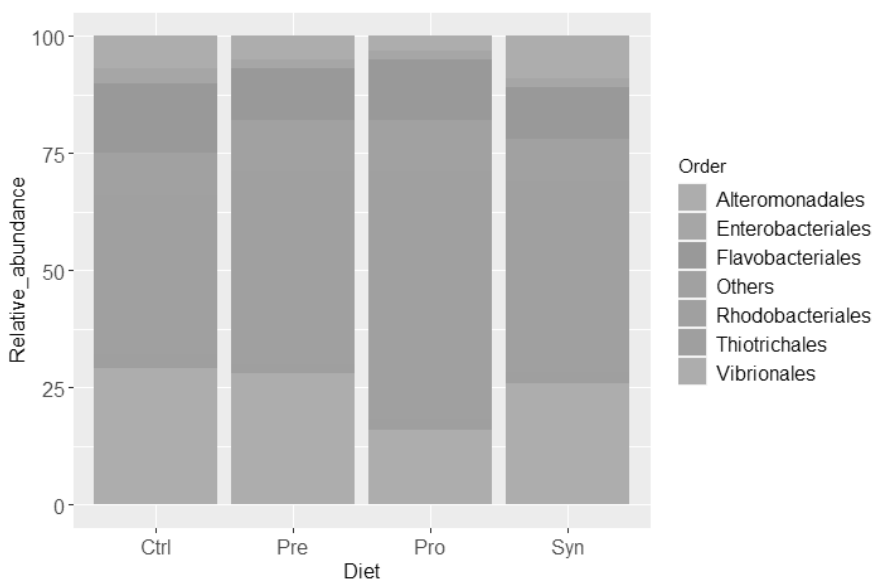

Figure 2. Relative abundance (\%) of bacteria, at order level, in shrimps fed during 4-weeks with the control (Ctrl), prebiotic (Pre), probiotic (Pro), and symbiotic (Syn) diets.

Figura 2. Abundancia relativa (\%) de bacterias a nivel de orden en camarones alimentados durante 4 semanas con las dietas control (Ctrl), prebiótica (Pre), probiótica (Pro) y simbiótica (Syn).

ceae family. In this regard, the Pro treatment presented the lowest proportion among treatments with $16 \%$, followed by the synbiotic with $26 \%$, and prebiotic and control with 28 and $29 \%$, respectively; in all cases, this family was represented entirely by the Vibrio genus. In the case of Flavobacteriales order level, represented by the Flavobacteriaceae family, control treatment showed $15 \%$ relative abundance in contrast to $13 \%$ in Pro, and $11 \%$ in Pre and Syn treatments.

In the case of probiotic bacteria related to diets, at class taxonomic level, Bacilli bacteria were more abundant in prebiotic treatment $(2 \%)$ than in probiotic, synbiotic $(0.5 \%$ each), and control ( $0.4 \%)$. In terms of genus abundance, Lactobacillus was absent in shrimp fed with control treatment, whereas those fed with prebiotic represented $0.02 \%$ of total bacteria, and $<0.01 \%$ in probiotic and synbiotic treatments. In the case of Bacillus, probiotic and synbiotic treatments 
showed 0.05 and $0.04 \%$ abundance, prebiotic $0.03 \%$, and control $0.01 \%$. Among different treatments, 20 species were identified including five species of Vibrionaceae; Vibrio furnissii was the most abundant for control treatment (3\%); whereas Vibrio antiquarius was the dominant species present for the rest of treatments (3-4\%).

According to the Chao index, bacterial richness estimator index values among treatments ranged from 1,567 to 2,123 , where Pro and Syn treatments, both with probiotics in the feed, resulted with higher values than those presented in Ctrl and Pre dietary treatments (Table 3). In terms of diversity assessed by the Shannon index among treatments, values ranged from 3.03 to 3.57. Simpson index values ranged from 0.14 to 0.23 , where Pre and Syn treatments showed higher diversity among treatments.

Table 3. Number of OTUs, richness estimation (Chao1), and diversity estimation (Shannon and Simpson) of intestinal community bacteria, of shrimp fed experimental diets after 4-weeks.

Tabla 3. Numero de OTUs, estimación de riqueza (Chao1), y estimación de diversidad (Shannon y Simpson) de las comunidades bacterianas del intestino del camarón, alimentado con las dietas experimentales durante 4 semanas

\begin{tabular}{|c|c|c|c|c|}
\hline & \multicolumn{4}{|c|}{ Diets } \\
\hline & Ctrl & Pre & Pro & Syn \\
\hline OTUs & $340 \pm 80$ & $496 \pm 12$ & $687 \pm 115$ & $650 \pm 30$ \\
\hline \multicolumn{5}{|l|}{$\begin{array}{l}\text { Richness } \\
\text { estimator }\end{array}$} \\
\hline Chao1 & $1,567 \pm 0.57$ & $1,719 \pm 0.57$ & $1,938 \pm 0.57$ & $2,123 \pm 1.15$ \\
\hline \multicolumn{5}{|l|}{$\begin{array}{l}\text { Diversity } \\
\text { estimators }\end{array}$} \\
\hline Shannon & $3.03 \pm 0.14$ & $3.52 \pm 0.07$ & $3.30 \pm 0.40$ & $3.57 \pm 0.12$ \\
\hline Simpson & $0.17 \pm 0.12$ & $0.20 \pm 0.03$ & $0.19 \pm 0.08$ & $0.23 \pm 0.09$ \\
\hline
\end{tabular}

\section{DISCUSSION}

The importance of gastrointestinal microbiota on host health and growth has been documented. The objective of probiotics and prebiotics in the feed is to induce favorable intestinal bacteria to promote growth, improve pathogen resistance and the immune response. The inclusion of 0.2 $0.8 \%$ inulin has proved to enhance shrimp growth (Li et al., 2020; Zhou et al., 2020), however, in the present work no difference on shrimp growth was evident, when included without probiotic, compared to $\mathrm{Ctrl}$ diet as reported by other authors with inulin inclusion levels between 0 and $1 \%$ (Luna-González et al., 2012; Partida-Arangure et al., 2013). This discrepancy may be associated to microorganism community present in the culture system. The use of inulin has been proven to be a good source of nutrients to promote probiotic bacteria from Lactobacillus and Bacillus genus (Savedboworn et al., 2018; Zherebtsov et al., 2002), providing a wide range of exoenzymes, including inulinase, that allow using inulin as source of carbon (Saha, 2006; Zherebtsov et al., 2002). Bacillus sp. and Lactobacillus sp. included in feed may also enhance shrimp protease, lipase, amylase, and cellulase activities, which suggests a better use of the nutrients contained in the feed and reflected in improvement of growth and feed efficiency utilization (Kongnum and Hongpattarakere, 2012; Zheng et al., 2017).

In the present study, the final weight of shrimps fed Pro treatment was higher than shrimps fed the control diet (Ctrl), but not significantly different $(P>0.05)$. Wang et al. (2019) described that the inclusion of Lactobacillus pentosus or Bacillus subtilis at $1 \times 10^{6} \mathrm{CFU} \mathrm{g}^{-1}$ in feed, improved weight gain in white shrimp. Similar effect was shown when the inclusion of probiotic Bacillus (B. subtilis and B. licheniformis) in the diet at $1 \times 10^{4}$ and $1 \times 10^{8} \mathrm{CFU} \mathrm{g}^{-1}$ significantly improved growth performance and feed utilization efficiency in $L$. vannamei (Sadat Hoseini Madani et al., 2018). In the case of the synbiotic treatment (Syn), shrimp growth and feed utilization efficiency improved in contrast to the $\mathrm{Ctrl}$ diet. Similar results were shown by Huyn et al. (2018), when shrimp fed with a synbiotic diet composed of Lactobacillus plantarum and galactooligosaccharide improved shrimp weight gain; nevertheless, the use of the probiotic alone showed no significant differences compared to the control diet, highlighting the importance of the presence of the prebiotic in the diet. The synergism between prebiotics and probiotics to improve shrimp growth (Boonanuntanasarn et al., 2016; Munaeni et al., 2014) has been suggested by the indirect and direct release of extracellular bacterial digestive enzymes and bioactive compounds that, in conjunction with the activation of the digestive enzymes of the host, improve the efficiency of feed utilization (Huynh et al., 2017).

After sequencing analysis, between 35 and $40 \%$ of the reads were classified within a genus or species. The use of the probiotic in the feed (Pro and Syn treatments) increased the shrimp intestinal bacterial richness according to the Chao index. Inclusion of prebiotic (Pre and Syn) in the feed promoted higher bacterial diversity according to both Shannon and Simpson indices. The increase of species richness in intestinal microbiota in L. vannamei has been also reported with the use of synbiotic composed of galactooligosaccharide and $L$. plantarum (Huynh et al., 2019), Bacillus sp. probiotic, honey prebiotic or a mix of them (synbiotic) (Hasyimi et al., 2020), suggesting that synbiotics in feed may modulate intestinal bacterial community.

The dominant bacterial group in shrimps fed the four treatments was the phylum Proteobacteria, which has been reported to be highly abundant in both healthy or diseased shrimp (Dai et al., 2018; Zheng et al., 2017), and also in shrimp fed probiotics and synbiotics included in the diet (Hasyimi et al., 2020). Differences in the Proteobacteria abundance due to the diet effect may also relate to shrimp size as observed by Dai et al. (2018), who found a temporal variation in shrimp gut microbiota composition (between 8 to $9 \mathrm{~g}$ ). Microbiome changes also occur between culture stages, as observed in L. vannamei larvae, being Proteobacteria the most abundant phylum (Zheng et al., 2017). Some bacteria from the Proteobacteria phylum serve as a direct source of nutrients (Moss, 
2002), and could improve feed digestion due to their digestive enzymes that may enhance nutrient utilization in shrimp (Wainwright and Mann, 1982). A diverse microbial community has been suggested to improve the degradation of low or indigestible substrates, which may increase the efficiency of feed utilization (Cottrell and Kirchman, 2003).

Shrimps fed the four treatments presented a high abundance of Bacteroidetes (8-19\%) and Actinobacteria (2-3 $\%)$, the last reported as abundant in healthy shrimps (5.6 \%), compared to diseased shrimps (0.1\%) (Dai et al., 2018). Proteobacteria, Bacteroides, Actinobacteria, and Firmicutes were found in all treatments, and are considered natural microbiota in the penaeid shrimp gut (Rungrassamee et al., 2014; Tzuc et al., 2014).

At family taxonomic level, a similar abundance of Flavobacteriaceae was found among treatments, which has been described as abundant in healthy farmed shrimp (Xiong et al., 2015; Zheng et al., 2017). Likewise, some specialized bacteria belonging to this family can degrade complex compounds including structural polysaccharides such as chitin from shrimp exoskeleton (Kirchman, 2002; Williams et al., 2013), implying a beneficial effect on pond water quality.

The nutrition strategy, including diets with prebiotics, probiotics, and synbiotics, represents an alternative to the use of antibiotics to control pathogenic bacteria including some Vibrio species (Johnson, 2013; Kewcharoen and Srisapoome, 2019). According to our results, shrimps fed with probiotics decreased the abundance of Vibrio sp. compared to the control treatment, as reported in the freshwater prawn Macrobrachium rosembergi fed with the inclusion of the probiotic Lactobacillus that showed an inhibitory effect on the gram-negative bacteria in the intestine (Venkat et al., 2004). Moreover, a previous study with the inclusion in feed of $B$. subtilis at $10^{5} \mathrm{CFU} \mathrm{g}^{-1}$, produced antimicrobial activity against pathogenic Vibrio species, with a reduction on shrimp mortality (Balcázar and Rojas-Luna, 2007). In the same way, the inoculation of $10^{6} \mathrm{CFU} \mathrm{ml}^{-1}$ of Lactobacillus $s p$. in water reduced the prevalence of pathogenic Vibrio in brine shrimp culture (Quiroz-Guzmán et al., 2018). The Vibrionaceae reduction in shrimps fed the probiotic diet (Pro) resulted in an increase of Rhodobacteraceae family, which has been reported at higher abundance in healthy shrimp as compared to diseased shrimps (Dai et al., 2018).

In the case of the Syn treatment, a reduction in Vibrio $s p$. abundance compared to the control treatment was observed. This result agrees with that observed in the same species, when L. plantarum and galactooligosaccharide synbiotic was included in the diet (Huynh et al., 2019), as well as for Penaeus japonicus (Zhang et al., 2011) fed a Bacillus sp. and isomaltooligosaccharides supplemented diet. The use of a mix of $B$. subtilis with $\beta$-glucan as prebiotic included in feed, also reduced the prevalence of Vibrio sp. in shrimp intestine, in contrast to $\beta$-glucan alone (Boonanuntanasarn et al., 2016). The reduction of Vibrio abundance by the use of synbiotics in the diet (oligosaccharides from sweet potato and Bacillus sp. NP5) has been related to an increase of total bacterial count in L. vannamei (Munaeni et al., 2014). Nevertheless, in the present work, Vibrio in the prebiotic treatment was similar to the control treatment. Vibrionaceae abundance may be affected by the source of the prebiotic employed; in the case of $\beta$-glucan, it has been reported that Vibrio abundance in shrimp gut is not affected when included alone in feed (Boonanuntanasarn et al., 2016). In turn, some Vibrio species may efficiently use inulin as a source of carbon to proliferate, as reported by Mahious et al. (2006) in turbot larvae. In this regard, the potential benefits of including inulin to the shrimp diet seems to be closely related to the natural microbial community and the introduced microorganism (probiotics) in the culture system.

\section{CONCLUSIONS}

In conclusion, we found that the synbiotic included in the diet improved shrimp growth, and the probiotic employed (B. subtilis and Lactobacillus $s p$.) reduced the relative abundance of Vibrio $s p$. in the shrimps' intestine; nevertheless, when combined with a prebiotic (inulin), this effect was reduced.

\section{ACKNOWLEDGMENTS}

This study was supported by Consejo Nacional de Ciencia y Tecnología (CONACYT, Mexico) through Grant No. 2015-01-887. We are thankful to Samuel Echeverria and Omar Camorlinga from Larvas Gran Mar, SA de CV, for kindly donate the shrimp juveniles, and Sandra de la Paz-Reyes from the Laboratory of Aquaculture Nutrition at CIBNOR for all the facilities and technical support during the experiments.

\section{REFERENCES}

Alagappan, K.M., Deivasigamani, B., Somasundaram, S.T., Kumaran, S. 2010. Occurrence of Vibrio parahaemolyticus and its specific phages from shrimp ponds in east coast of India. Current microbiology, 61, 235-240.

AOAC. 2005. Official methods of analysis of the association of analytical chemists international, 18th ed. Gathersburg, MD, U.S.A.

Balcázar, J.L., Rojas-Luna, T. 2007. Inhibitory activity of probiotic Bacillus subtilis UTM 126 against Vibrio species confers protection against vibriosis in juvenile shrimp (Litopenaeus vannamei). Current Microbiology, 55, 409-412.

Boonanuntanasarn S., Wongsasak, U., Pitaksong, T., Chaijamrus, S. 2016. Effects of dietary supplementation with $\beta$-glucan and synbiotics on growth, haemolymph chemistry, and intestinal microbiota and morphology in the Pacific white shrimp. Aquaculture Nutrition, 22, 837-845.

Cottrell, M., Kirchman, D. 2003. Contribution of major bacterial groups to bacterial biomass production (thymidine and leucine incorporation) in the Delaware estuary. Limnology and Oceanography, 48, 168-178.

Dai, W., Yu, W., Xuan, L., Tao, Z., Xiong, J. 2018. Integrating molecular and ecological approaches to identify potential polymicrobial pathogens over a shrimp disease progression. Applied Microbiology and Biotechnology, 102, 3755-3764.

Ebeling, M.E. 1968. The Dumas method for nitrogen in feeds. Journal of the Association of Official Analytical Chemists, 51, 766-770. 
Elizondo-González, R., Quiroz-Guzmán, E., Escobedo-Fregoso, C., Magallón-Servín, P., \& Peña-Rodríguez, A. (2018). Use of seaweed Ulva lactuca for water bioremediation and as feed additive for white shrimp Litopenaeus vannamei. PeerJ, 6, e4459.

García-Rodríguez, R. 2003. Relevancia de las bacterias ácido lácticas en los diferentes estadios del cultivo del camarón. Bachelor dissertation. UABCS University, La Paz, B.C.S., México.

Hai, N.V. 2015. The use of probiotics in aquaculture. Journal of Applied Microbiology, 119, 917-935.

Hammer, Ø., Harper, D.A., Ryan, P.D. 2001. PAST: Paleontological statistics software package for education and data analysis. Palaeontologia electronica, 4(1), 9.

Hasyimi, W., Widanarni, W., Yuhana, M. 2020. Growth Performance and Intestinal Microbiota Diversity in Pacific White Shrimp Litopenaeus vannamei Fed with a Probiotic Bacterium, Honey Prebiotic, and Synbiotic. Current Microbiology, 77, 2982-2990.

Huynh, T.G., Shiu, Y.L., Nguyen, T.P., Truong, Q.P., Chen, J.C., Liu, C.H. 2017. Current applications, selection, and possible mechanisms of actions of synbiotics in improving the growth and health status in aquaculture: A review. Fish and Shellfish Immunology, 64, 367-382.

Huynh, T.G., Chi, C.C., Nguyen, T.P., Tran, T.T.T.H., Cheng, A.C., Liu, C.H. 2018. Effects of synbiotic containing Lactobacillus plantarum 7-40 and galactooligosaccharide on the growth performance of white shrimp, Litopenaeus vannamei. Aquaculture Research, 49, 2416-2428.

Huynh,T.G., Hu, S.Y., Chiu, C.S., Truong, Q.P., Liu, C.H.2019. Bacterial population in intestines of white shrimp, Litopenaeus vannamei fed a synbiotic containing Lactobacillus plantarum and galactooligosaccharide. Aquaculture Research, 50, 807817.

Jamal, M.T., Abdulrahman, I.A., Al Harbi, M., Chithambaran, S. 2019. Probiotics as alternative control measures in shrimp aquaculture: A review. Journal of Applied Biology \& Biotechnology, 7, 69-77.

Johnson, C.N. 2013. Fitness factors in Vibrios: A Mini-review. Microbial Ecology, 65, 826-851.

Klindworth, A., Pruesse, E., Schweer, T., Peplies, J., Quast, C., Horn, M., Glöckner, F.O., 2013. Evaluation of general 16S ribosomal RNA gene PCR primers for classical and next-generation sequencing-based diversity studies. Nucleic Acids Research, 41:e1.

Kesarcodi-Watson, A., Kaspar, H., Lategan, M.J., Gibson, L. 2008. Probiotics in aquaculture: The need, principles and mechanisms of action and screening processes. Aquaculture, 274, 1-14.

Kewcharoen, W., Srisapoome, P. 2019. Probiotic effects of Bacillus spp. from Pacific white shrimp (Litopenaeus vannamei) on water quality and shrimp growth, immune responses, and resistance to Vibrio parahaemolyticus (AHPND strains). Fish \& shellfish immunology, 94, 175-189.

Kirchman, D.L. 2002. The ecology of Cytophaga-Flavobacteria in aquatic environments. FEMS Microbiology Ecology, 39, 91-100.

Kongnum, K., Hongpattarakere, T. 2012. Effect of Lactobacillus plantarum isolated from digestive tract of wild shrimp on growth and survival of white shrimp (Litopenaeus vannamei) challenged with Vibrio harveyi. Fish and Shellfish Immunology, 32, 170-177.

Kumar, V., Roy, S., Meena, D.K., Sarkar, U.K. 2016. Application of probiotics in shrimp aquaculture: importance, mechanisms of action, and methods of administration. Reviews in Fisheries Science \& Aquaculture, 24, 342-368.

Li, Y., Yuan, W., Zhang, Y., Liu, H., Dai, X. 2020. Single or combined effects of dietary arabinoxylan-oligosaccharide and inulin on growth performance, gut microbiota, and immune response in Pacific white shrimp Litopenaeus vannamei. Journal of Oceanology and Limnology, 1-14.

Li, P., Burr, G.S., Gatlin, D.M., Hume, M.E., Patnaik, S., Castille, F.L., Lawrence, A.L. 2007. Dietary supplementation of shortchain fructooligosaccharides influences gastrointestinal microbiota composition and immunity characteristics of Pacific white shrimp, Litopenaeus vannamei, cultured in a recirculating system. The Journal of Nutrition, 137, 27632768.

Liu, C.H., Chiu, C.S., Ho, P.L., Wang, S.W. 2009. Improvement in the growth performance of white shrimp, Litopenaeus vannamei, by a protease-producing probiotic, Bacillus subtilis E20, from natto. Journal of Applied Microbiology, 107, 1031-1041.

Liu, K.F., Chiu, C.H., Shiu, Y.L., Cheng, W., Liu, C.H. 2010. Effects of the probiotic, Bacillus subtilis E20, on the survival, development, stress tolerance, and immune status of white shrimp, Litopenaeus vannamei larvae. Fish and Shellfish Immunology, 28, 837-844.

Luna-González, A., Almaraz-Salas, J.C., Fierro-Coronado, J.A., Flores-Miranda, M.C., González-Ocampo, H.A., Peraza-Gómez, V. 2012. The prebiotic inulin increases the phenoloxidase activity and reduces the prevalence of WSSV in whiteleg shrimp (Litopenaeus vannamei) cultured under laboratory conditions. Aquaculture, 362-363, 28-32.

Mahious, A.S., Gatesoupe, F.J., Hervi, M., Metailler, R., Ollevier, F. 2006. Effect of dietary inulin and oligosaccharides as prebiotics for weaning turbot, Psetta maxima (Linnaeus, C. 1758). Aquaculture International, 14, 219- 229.

Manning, T.S., Gibson, G.R. 2004. Prebiotics. Best Practice \& Research Clinical Gastroenterology, 18, 287-298.

Martínez-Córdova, L.R., Emerenciano, M., Miranda-Baeza, A., Martínez-Porchas, M. 2015. Microbial-based systems for aquaculture of fish and shrimp: an updated review. Reviews in Aquaculture, 7, 131-148.

Martinez, J.L. 2009. Environmental pollution by antibiotics and by antibiotic resistance determinants. Environmental Pollution, 157, 2893-2902.

Moss, S.M. 2002. Dietary importance of microbes and detritus in Penaeid shrimp aquaculture. In: Lee, C.S., O'Bryen, P. (Eds.), Microbial approaches to aquatic nutrition within environmentally sound aquaculture production systems. World Aquaculture Society, Baton Rouge, LA, 1-18 pp.

Munaeni, W., Yuhana, M., Widanarni, W. 2014. Effect of microencapsulated synbiotic at different frequencies for luminous Vibriosis control in White shrimp (Litopenaeus vannamei). Microbiology Indonesia, 8, 73-80.

Ninawe, A.S., Selvin, J. 2009. Probiotics in shrimp aquaculture: Avenues and challenges. Critical Reviews in Microbiology, 35, 43-66.

Novriadi, R. 2016. Vibriosis in aquaculture. Omni-Akuatika, 12(1).

Olmos, J., Acosta, M., Mendoza, G., Pitones, V. 2020. Bacillus subtilis, an ideal probiotic bacterium to shrimp and fish aquaculture that increase feed digestibility, prevent microbial diseases, and avoid water pollution. Archives of microbiology, 202, 427-435.

Partida-Arangure, B.O., Luna-González, A., Fierro-Coronado, J.A., Flores-Miranda, C., González-Ocampo, H.A. 2013. Effect of inulin and probiotic bacteria on growth, survival, immune response, and prevalence of white spot syndrome virus 
(WSSV) in Litopenaeus vannamei cultured under laboratory conditions. African Journal of Biotechnology, 12, 3366-3375.

Peña-Rodríguez, A., Morales-Alvarado, G., Elizondo-González, R., Mendoza-Carrión, G., Tovar-Ramírez, D., Escobedo-Fregoso, C. 2020. Seaweed single cell detritus effects on the digestive enzymes activity and microbiota of the oyster Crassostrea gigas. Journal of Applied Phycology, 32, 3481-3493.

Quiroz-Guzmán, E., Vázquez-Juárez, R., Luna-González, A., Balcázar, J.L., Barajas-Sandoval, D.R., Martínez-Díaz, S.F. 2018. Administration of probiotics improves the brine shrimp production and prevents detrimental effects of pathogenic Vibrio species. Marine Biotechnology, 20, 512-519.

Rashid, M., Stingl, U. 2015. Contemporary molecular tools in microbial ecology and their application to advancing biotechnology. Biotechnology Advances, 33, 1755-1773.

Ringø, E., Olsen, R.E., Gifstad, T., Dalmo, R.A., Amlund, H., Hemre, G.I., Bakke, A.M. 2010. Prebiotics in aquaculture: A review. Aquaculture Nutrition, 16, 117-136.

Rungrassamee, W., Klanchui, A., Maibunkaew, S., Chaiyapechara, S., Jiravanichpaisal, P., Karoonuthaisiri, N. 2014. Characterization of intestinal bacteria in wild and domesticated adult black tiger shrimp (Penaeus monodon). PLoS ONE, 9, e91853.

Sadat Hoseini Madani, N., Adorian, T.J., Ghafari Farsani, H., Hoseinifar, S.H. 2018. The effects of dietary probiotic Bacilli (Bacillus subtilis and Bacillus licheniformis) on growth performance, feed efficiency, body composition and immune parameters of whiteleg shrimp (Litopenaeus vannamei) postlarvae. Aquaculture Research, 49(5), 19261933.

Saha, B.C. 2006. Production of mannitol from inulin by simultaneous enzymatic saccharification and fermentation with Lactobacillus intermedius NRRL B-3693. Enzyme and Microbial Technology, 39, 991-995.

Savedboworn, W., Niyomrat, S., Naknovn, J., Phattayakorn, K. 2018. Impact of inulin on viability and storage stability of probiotic Lactobacillus plantarum TISTR 2075 in fermented rice extract. Agriculture and Natural Resources, 51, 463-469.

Thompson, F.L., lida, T., Swings, J. 2004. Biodiversity of Vibrios. Microbiology and Molecular Biology Reviews, 68, 403-431.

Tzuc, J., Escalante, D., Rojas-Herrera, R, Gaxiola-Cortés, G., Ortiz, M. 2014. Microbiota from Litopenaeus vannamei: digestive tract microbial community of Pacific white shrimp (Litopenaeus vannamei). SpringerPlus, 3, 280.

Vargas-Albores, F., Porchas-Cornejo, M.A., Martínez-Porchas, M., Villalpando-Canchola, E., Gollas-Galván, T., MartínezCórdova, L.R. 2017. Bacterial biota of shrimp intestine is significantly modified by the use of a probiotic mixture: a high throughput sequencing approach. Helgoland Marine Research, 71, 5 .

Venkat, H.K., Sahu, N.P., Jain, K.K. 2004. Effect of feeding Lactobacillus-based probiotics on the gut microflora, growth and survival of postlarvae of Macrobrachium rosenbergii (de Man). Aquaculture Research, 35, 501-507.

Verschuere, L., Rombaut, G., Sorgeloos, P., Verstraete, W. 2000. Probiotic bacteria as biological control agents in aquaculture. Microbiology and Molecular Biology Reviews, 64, 655-671.

Yilmaz P, Parfrey LW, Yarza P, Gerken J, Pruesse E, Quast C, Schweer T, Peplies J, Ludwig W, Glöckner FO (2014) The
SILVA and "All-species Living Tree Project (LTP)" taxonomic frameworks. Nucleic Acids Research, 42:D643-D648.

Wainwright, P.F., Mann, K.H. 1982. Effect of antimicrobial substances on the ability of the mysid shrimp Mysis stenolepis to digest cellulose. Marine Ecology Progress Series, 7, 309-313.

Wang, Y.C., Hu, S.Y., Chiu, C.S., Liu, C.H. 2019. Multiple-strain probiotics appear to be more effective in improving the growth performance and health status of white shrimp, Litopenaeus vannamei, than single probiotic strains. Fish \& shellfish immunology, 84, 1050-1058.

Williams, T.J., Wilkins, D., Long, E., Evans, F., Demaere, M.Z., Raftery, M.J., Cavicchioli, R. 2013. The role of planktonic Flavobacteria in processing algal organic matter in coastal East Antarctica revealed using metagenomics and metaproteomics. Environmental Microbiology, 15, 1302-1317.

Wongsasak, U., Chaijamrus, S., Kumkhong, S., Boonanuntanasarn, S. 2015. Effects of dietary supplementation with $\beta$-glucan and synbiotics on immune gene expression and immune parameters under ammonia stress in Pacific white shrimp. Aquaculture, 436, 179-187.

Xiong, J., Wang, K., Wu, J., Qiuqian, L., Yang, K., Qian, Y., Zhang, D. 2015. Changes in intestinal bacterial communities are closely associated with shrimp disease severity. Applied Microbiology and Biotechnology, 99, 6911-6919.

Zhang, Q., Tan, B., Mai, K., Zhang, W., Ma, H., Ai, Q., Wang, X., Liufu, Z. 2011. Dietary administration of Bacillus (B. licheniformis and $B$. subtilis) and isomaltooligosaccharide influences the intestinal microflora, immunological parameters and resistance against Vibrio alginolyticus in shrimp, Penaeus japonicus (Decapoda: Penaeidae). Aquaculture Research, 42, 943-952.

Zheng, C.N., Wang, W. 2017. Effects of Lactobacillus pentosus on the growth performance, digestive enzyme and disease resistance of white shrimp, Litopenaeus vannamei (Boone, 1931). Aquaculture Research, 48(6), 2767-2777.

Zheng, X., Duan, Y., Dong, H., Zhang, J. 2017. Composition, diversity and function of intestinal microbiota in pacific white shrimp (Litopenaeus vannamei) at different culture stages. PeerJ, 5, e3986.

Zherebtsov, N.A., Shelamova, S.A., Abramova, I.N. 2002. Biosynthesis of inulinases by Bacillus bacteria. Applied Biochemestry and Microbiology, 38, 544-548.

Zhou, L., Li, H., Qin, J.G., Wang, X., Chen, L., Xu, C., Li, E. 2020. Dietary prebiotic inulin benefits on growth performance, antioxidant capacity, immune response and intestinal microbiota in Pacific white shrimp (Litopenaeus vannamei) at low salinity. Aquaculture, 518, 734847.

Zhou, J., Fang, W., Yang, X., Zhou, S., Hu, L., Li, X., Qi, X., Su, H., $\mathrm{Xie}, \mathrm{L}$. 2012. A nonluminescent and highly virulent Vibrio harveyi strain is associated with "bacterial white tail disease" of Litopenaeus vannamei shrimp. PLoS ONE, 7, e29961.

Zhou, X.X., Wang, Y.B., Li, W.F. 2009. Effect of probiotic on larvae shrimp (Penaeus vannamei) based on water quality, survival rate and digestive enzyme activities. Aquaculture, 287, 349353.

Zubaidah, A., Yuhana, M., Widanarni. 2015. Encapsulated synbiotic dietary supplementation at different dosages to prevent Vibriosis in white shrimp, Litopenaeus vannamei. HAYATI Journal of Biosciences, 22, 163-168. 